\title{
ІНСТИТУТ ВІЙСЬКОВОГО КАПЕЛАНСТВА В УКРАЇНІ: СТАНОВЛЕННЯ, РОЗВИТОК В УМОВАХ СУЧАСНОЇ ГІБРИДНОЇ ВІЙНИ РОСІЙСЬКОЇ ФЕДЕРАЦІЇ
}

\section{Ткачук П. О.}

\section{ВСТУП}

Збройна агресія Російської Федерації (2014р.) привернула увагу суспільства до численних проблем Збройних Сил України, серед яких - до останнього часу законодавчо не врегульований статус капеланів. «За останні п’ять років слово «капелан» міцно увійшло в лексикон українців, - констатують учені. - Хоча існування капеланства не передбачає обов'язковий хід війни чи воєнних дій, адже капелани потрібні у пенітенціарній службі, в госпіталях, у війську - скрізь, де є люди, які з тих чи інших причин обмежені у доступі до задоволення своїх духовним потреб, в нашому суспільстві питання капеланства набуло особливої ваги саме через початок бойових дій на сході країни» ${ }^{1}$. В умовах війни з Російською Федерацією військові капелани зайняли специфічне місце у військових формуваннях України, опікуючись військовослужбовцям на фронті та допомагаючи мінімізувати бойові психічні травми в учасників АТО / OOC $^{2}$.

В українській історичній, політологічній, військовій думці проблема правового статусу капела набула особливої актуальності після початку російсько-української війни, адже чимало священнослужителів вирушили з душпастирською місісю у південносхідні регіони України. Специфіка капеланської служби порушується в історико-мемуарній праці «Капелани. На службі Богу і Україні» ${ }^{3}$ (особливо цікаві сюжетні лінії, які стосуються особливостей капеланського служіння на фронті під час протидії російській агресії $)$,

${ }_{2}^{1}$ Бути поруч - завдання капелана. URL : http://olivebranch.org.ua/.

2 Проблеми служби військових капеланів України в умовах агресії Російської Федерації: аналітична доповідна. URL : https://niss.gov.ua/sites/default/files/201608/kapelanu-d05c2.pdf.

Капелани. На службі Богу і Україні / Уклад.: Тетяна Ковтунович, Тетяна Привалко ; Укр. ін-т нац. пам'яті. Київ : ФОП Гончарук А.Б., 2019. 620 с.

${ }^{4}$ «Капелани. на службі Богу і Україні». Інститут презентує спогади військових священиків. URL : https://uinp.gov.ua/pres-centr/novyny/3104. 
становлення інституту військового капеланства - у працях С. Ярмуся 5 , О. Уткіна ${ }^{6}$, В. Танчера ${ }^{7}$, П. Рабіновича ${ }^{8}$, В. Журавського ${ }^{9}$. У руслі досліджуваної проблеми викликають зацікавлення дослідження Е. Дробка «Державне регулювання у сфері забезпечення душпастирської опіки військовослужбовців Збройних Сил України та створення інституту військового капеланства» ${ }^{10}$, І. Чорної «Церква i армія: зарубіжний досвід та українські реалії» ${ }^{11}$ С. Здіорука «Служба військових капеланів: досвід функціонування в іноземних збройних силах» та ін. ${ }^{12}$.

\section{1. Становлення інституту військового капеланства в Україні}

Перші кроки на шляху до визнання Українською державою інституту військового капеланства були зроблені у 1990-х рp. Зокрема, починаючи з 1996 року в різних конфесіях «починають формуватися напрями діяльності щодо задоволення духовних потреб військовослужбовців, призначаються відповідальні за дані напрями, створюються відповідні структури» ${ }^{13}$. Проте тільки після Помаранчевої революції почалась активізація військово-церковного співробітництва. Продовженням стало видання Міністром оборони України директиви від 21 квітня 2006 року № Д-25 «Про

5 Ярмусь С. Збройні Сили і феномен військового капеланства. Армія $i$ духовність: свобода совісті та віровизнання. Матеріали міжнародної науковопрактичної конференції. К., 1995. С. 111-112.

${ }^{6}$ Уткін О. Конфлікти на національно-конфесійному грунті у Збройних Силах України та заходи 3 їх запобігання. Українське релігієзнавство. Київ, 1997. № 5. C. 52-55.

7 Танчер В. Свобода совісті - важлива умова культурного розвитку особи військовослужбовця. Українське релігієзнавство. Бюлетень. Київ, 1998. № 7. C. 31-33.

8 Рабінович П.М., Коваленко С.О. Свобода віросповідання і загальний військовий обов'язок. Драгоманівський збірник “Вільна спілка” та сучасний український конституціоналізм. Львів. 1996. С. 221-226.

9 Журавський В. Церква і армія: співпраця у формуванні воїна-громадянина. Вечірній Київ. 1996. 30 жовтня С. 6

to Дробко Е. Державне регулювання у сфері забезпечення душпастирської опіки військовослужбовців Збройних Сил України та створення інституту військового капеланства. URL : http://lvivacademy.com/vidavnitstvo_1/visnyk14/fail/drobko.pdf.

11 Чорна I. Церква і армія: зарубіжний досвід та українські реалії. URL : https://www.ngu.gov.ua/en/node/4748.

12 Здіорук С. Служба військових капеланів: досвід функціонування в іноземних збройних силах. Стратегічні пріоритети. 2009. № 1(10) . С. 236-245.

13 Концепція душпастирської опіки у Збройних Силах України. URL : https://www.mil.gov.ua/diyalnist/zvyazki-z-gromadskistyu/rada-u-spravah-dushpastirskoiopiki-pri-ministerstvi-oboroni-ukraini/normativni-dokumenti-ta-metodichnirekomendaczii/2014/07/08/konczepcziya-dushpastirskoi-opiki-u-zbrojnih-silah-ukraini/. 
впорядкування питань задоволення релігійних потреб військовослужбовців Збройних Сил України». Цей документ підштовхнув до системної діяльності у цій сфері. У свою чергу, це призвело до утворення 1 листопада 2008 року в структурі Департаменту гуманітарної політики Міністерства оборони України сектору роботи з релігійними організаціями ${ }^{14}$.

Водночас 10 листопада 2008 р. Міністерство оборони України підписало «Меморандум про співпрацю у справах душпастирської опіки військовослужбовців Збройних Сил України» 3 усіма конфесіями України. Для налагодження ефективнішої співпраці релігійних організацій, вироблення єдиних підходів до впровадження інституту військового капеланства 29 квітня 2009 р. наказом Міністра оборони України від 17 березня 2009 р. № 115 було створено Раду у справах душпастирської опіки при Міністерстві оборони України. Її зусиллями підготовлено Концепцію душпастирської опіки у Збройних Силах України (затверджена відповідно до Наказу Міністра оборони України № 220 від 22 квітня 2011 р.) $)^{15}$. За словами заступника директора начальника відділу Департаменту військової освіти, науки, соціальної та гуманітарної політики Міністерства оборони України, iii підготовлено «з метою задоволення конституційних прав на свободу світогляду і віросповідання для військовослужбовців Збройних Сил України та членів їхніх сімей, за поданням Ради у справах душпастирської опіки при Міністерстві оборони України» ${ }^{16}$. На думку іï розробників, вона мала бути перехідним документом від нештатної душпастирської опіки до повноцінного інституту військового духовенства ${ }^{17}$.

У концепції наголошено, що головна мета душпастирської опіки військовослужбовців - забезпечити задоволення релігійних потреб військовослужбовців Збройних Сил України ${ }^{18}$. Душпастирська опіка військовослужбовців мала здійснюватися, виходячи 3 таких принципів:

14 Там само.

15 Там само.

16 Найближчим часом в українському війську буде запроваджено інститут військового духовенства. URL : https://www.mil.gov.ua/special/ news.html? article $=23111$.

17 Там само.

18 Концепція душпастирської опіки у Збройних Силах України. URL : https://www.mil.gov.ua/diyalnist/zvyazki-z-gromadskistyu/rada-u-spravah-dushpastirskoiopiki-pri-ministerstvi-oboroni-ukraini/normativni-dokumenti-ta-metodichnirekomendaczii/2014/07/08/konczepcziya-dushpastirskoi-opiki-u-zbrojnih-silah-ukraini/. 
- забезпечення конституційних прав громадянина на свободу світогляду і віросповідання;

- рівності усіх конфесій, віруючі яких проходять службу у Збройних Силах України, у можливостях задоволення релігійних потреб віруючих;

- пріоритетності бойової підготовки під час планування та проведення заходів душпастирської опіки військовослужбовців;

- невтручання священнослужителів у діяльність командування військових частин (підрозділів);

- невтручання військового командування у внутрішні справи релігійних організацій і міжконфесійні відносини;

- поваги, толерантного ставлення до представників інших конфесій та один до одного;

- недопущення прозелітизму, під яким розуміються будь-які дії, за допомогою яких здійснюються спроби збільшити кількість власних віруючих за рахунок послідовників інших конфесій;

- узгодження всіх питань щодо використання будівель та приміщень, які збудовані (відновлені, пристосовані) для виконання культових потреб на території військових частин, містечок, військових навчальних закладів, шпиталів тощо, на основі толерантного ставлення до представників інших конфесій ${ }^{19}$.

Основне завдання душпастирської опіки, на думку розробників Концепції: навчання віруючих військовослужбовців основам віровчення; виховання любові до Бога, готовності до самопожертви заради Батьківщини і ближніх; розвиток у військовослужбовців стійких моральних якостей - справедливості, мужності, поміркованості, дисциплінованості, вірності своїм обов'язкам тощо; виховання почуття любові до Батьківщини, поваги до загальнолюдських цінностей, культурного та духовного надбання ${ }^{20}$.

Відповідно до Концепції військовому священнослужителю надано право: відправляти богослужіння й інші релігійні служби та обряди у визначений час та у відповідному місці; у встановленому порядку перебувати на території військової частини (підрозділу) чи в іншому місці здійснення душпастирської опіки; використовувати приміщення та майно, призначені для потреб душпастирської опіки; організовувати святкування у військовій частині релігійних свят; брати участь в облаштуванні місць проведення богослужінь та інших релігійних обрядів; звертатися зі скаргами до вищого

\footnotetext{
${ }^{19}$ Там само.

${ }^{20}$ Там само.
} 
командування 3 приводу порушень прав військовослужбовців на свободу совісті та віросповідання; давати поради та рекомендації командирам щодо релігійних питань, брати участь у виробленні рішень у цій сфері; організовувати доброчинну допомогу малозабезпеченим сім'ям військовослужбовців та працівників Збройних Сил України, хворим та госпіталізованим військовослужбовцям тощо ${ }^{21}$.

В аналітичній доповідній «Проблеми служби військових капеланів України в умовах агресії Російської Федерації» відзначено, що модернізація Збройних Сил України потребує не лише структурних змін військового управління, застосування стандартів НАТО в переозброєнні, але й створення якісно нових умов для духовногуманітарної та морально-психологічної підготовки військовослужбовців. «Особливістю цього процесу $є$ те, що серед особового складу українських збройних формувань значно збільшилась кількість віруючих військовослужбовців, що породило необхідність подальшого вдосконалення системної роботи 3 особовим складом та пошук ефективних форм i методів для підготовки його до виконання службово-бойових завдань. В умовах війни з Росією виникла також необхідність специфічної діяльності щодо мінімізації бойових психічних травм серед учасників АТО», йдеться у документі ${ }^{22}$.

Станом на 2014 р., час відкритої збройної агресії Російської Федерації, основоположним документом, який легалізовував службу військових капеланів, було Розпорядження Кабінету Міністрів України № 677-р «Про службу військового духовенства (капеланську службу) у Збройних Силах, Національній гвардії та Державній прикордонній службі» від 2 липня 2014 р. ${ }^{23}$.

У документі передбачено:

1. Міністерству оборони, Міністерству внутрішніх справ, Міністерству інфраструктури та Адміністрації Державної прикордонної служби:

- забезпечити організацію навчання військових священиків (капеланів) основ військової справи, а також їх військовогуманітарну та військово-психологічну підготовку;

21 Там само.

22 Проблеми служби військових капеланів України в умовах агресії Російської Федерації: аналітична доповідна. URL : https://niss.gov.ua/sites/default/files/201608/kapelanu-d05c2.pdf.

${ }^{23}$ Там само. 
- щороку інформувати Кабінет Міністрів України і Міністерство культури про стан служби військового духовенства (капеланської служби) та подавати відповідну статистичну звітність.

2. Міністерству соціальної політики підготувати пропозиції щодо доповнення Класифікатора професій професією, за якою забезпечується душпастирська опіка військовослужбовців i резервістів Збройних Сил, Національної гвардії, Державної спеціальної служби транспорту та Державної прикордонної служби.

3. Міністерству культури:

- проводити відповідний моніторинг та щокварталу подавати Кабінетові Міністрів України інформацію про проведену роботу ${ }^{24}$.

Для виконання вищезазначеного Рішення видано наказ Міністерства оборони України № 40 «Про затвердження Положення про службу військового духовенства (капеланську службу) у Збройних Силах України» від 27 січня 2015 р. зареєстрований у Міністерстві юстиції України 14 лютого 2015 р. за № 161/26606 ${ }^{25}$. Згодом до Розпорядження Кабінету Міністрів України № 677-р «Про службу військового духовенства (капеланську службу) у Збройних Силах, Національній гвардії та Державній прикордонній службі» внесено зміни (Розпорядженням Кабінету Міністрів України № 964-р від 14 грудня 2016 р.), відповідно до яких запропоновано:

1. Міністерству оборони, Міністерству внутрішніх справ, Міністерству інфраструктури та Адміністрації Державної прикордонної служби:

- розробити та затвердити відповідно до компетенції положення про службу військового духовенства (капеланську службу) у Збройних Силах, Національній гвардії, Державній спеціальній службі транспорту та Державній прикордонній службі, визначивши, що священнослужителі, які запропоновані релігійними організаціями та успішно пройшли відбір, працевлаштовуються 3 укладенням відповідних трудових договорів у підрозділи Збройних Сил, Національної гвардії, Державної спеціальної служби транспорту та Державної прикордонної служби, належать до

\footnotetext{
${ }^{24}$ Про службу військового духовенства (капеланську службу) у Збройних Силах, Національній гвардії, Державній спеціальній службі транспорту та Державній прикордонній службі : Розпорядження Кабінету Міністрів України. URL : https://zakon.rada.gov.ua/laws/show/677-2014-\%D1\%80\#Text.

25 Найближчим часом в українському війську буде запроваджено інститут військового духовенства. URL : https://www.mil.gov.ua/special/news.html ?article $=23111$.
} 
персоналу Збройних Сил, Національної гвардії, Державної спеціальної служби транспорту та Державної прикордонної служби і $є$ військовими священиками (капеланами);

- здійснити у місячний строк після затвердження зазначених положень відбір осіб 3 числа священнослужителів, які запропоновані релігійними організаціями для забезпечення душпастирської опіки військовослужбовців і резервістів Збройних Сил, Національної гвардії, Державної спеціальної служби транспорту та Державної прикордонної служби, згідно з вимогами таких положень;

3. Міністерству культури:

- сприяти координації співпраці релігійних організацій 3 Міністерством оборони, Міністерством внутрішніх справ, Міністерством інфраструктури, Адміністрацією Державної прикордонної служби з питань служби військового духовенства (капеланської служби) ${ }^{26}$.

5 січня 2017 р. Міністерство юстиції зареєструвало Наказ Міністерства оборони України «Про затвердження Положення про службу військового духовенства (капеланську службу) у Збройних Силах України» ${ }^{27}$. Довгоочікуване Положення внесло суттєві зміни до інституту капеланства. Відповідно до документу службу військового духовенства (капеланську службу) у Збройних Силах України становлять:

- структурний підрозділ (посадові особи) Департаменту військової освіти, науки, соціальної та гуманітарної політики Міністерства оборони України;

- структурні підрозділи (посадові особи) Головного управління морально-психологічного забезпечення Збройних Сил України та органів військового управління Збройних Сил України;

- структурний підрозділ (посадові особи) Центру моральнопсихологічного забезпечення Збройних Сил України;

\footnotetext{
${ }^{26}$ Про службу військового духовенства (капеланську службу) у Збройних Силах, Національній гвардії, Державній спеціальній службі транспорту та Державній прикордонній службі : Розпорядження Кабінету Міністрів України. URL : https://zakon.rada.gov.ua/laws/show/677-2014-\%D1\%80\#Text.

7 Про затвердження Положення про службу військового духовенства (капеланську службу) у Збройних Силах України: Наказ Міністерства оборони України. URL : https://zakon.rada.gov.ua/laws/show/z0010-17\#Text.
} 
- військові священики (капелани) військових частин, військових навчальних закладів, установ та організацій Збройних Сил України

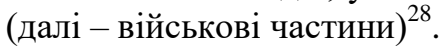

Положення санкціонувало створення Ради у справах душпастирської опіки при Міністерстві оборони України (РДпО) міжконфесійного консультативно-дорадчого органу, що діяв при Міністерстві оборони України та опікувався капеланами. Останні, відповідно до Положення, мали працювати учотирьох основоположних напрямах:

1) задоволення релігійних потреб військовослужбовців та членів їхніх сімей;

2) релігійно-освітня робота;

3) душпастирська опіка військовослужбовців та членів їх сімей;

4) соціально-доброчинна діяльність ${ }^{29}$.

Основними завданнями військового священика стали: організація та проведення молитов, богослужінь, благословень, урочистих і поминальних заходів та інших релігійних обрядів i культів, пов'язаних із задоволенням релігійних потреб військовослужбовців; виховання військовослужбовців на основі морального i духовного потенціалу релігійної та культурної спадщини українського народу; допомога військовослужбовцям у розвитку їхніх особистісних та колективних моральних якостей на основі братерства, мужності, хоробрості, відповідальності, поміркованості, стійкості, жертовності, дисциплінованості, розсудливості; ознайомлення військовослужбовців 3 основами релігійного вчення; виховання у військовослужбовців толерантного ставлення до людей 3 іншим світоглядом та релігійними переконаннями; ознайомлення особового складу 3 історією національного, культурного та релігійного становлення української державності; налагодження партнерських відносин із представниками релігійних організацій, які діють у місцях дислокації військових частин; участь у реабілітації особового складу, який потребує психологічної допомоги; всебічна душпастирська опіка та турботливе ставлення до військовослужбовців та членів їх сімей ${ }^{30}$.

Військовому священику надано право:

${ }^{28}$ Там само.

${ }^{29}$ Там само.

${ }^{30}$ Там само. 
- незалежно від релігійної приналежності сприяти реалізації прав особового складу на задоволення їхніх релігійних потреб;

- здійснювати богослужіння та інші релігійні обряди для військовослужбовців;

- проводити на добровільних засадах навчання військовослужбовців основам віровчення своєї релігійної організації;

- надавати пропозиції командуванню військових частин щодо облаштування місць проведення молитов, богослужінь та інших релігійних обрядів;

- звертатися із пропозиціями до командування 3 питань забезпечення дотримання прав військовослужбовців на свободу совісті та віросповідання;

- брати участь у службових нарадах із питань забезпечення реалізації прав особового складу на задоволення їхніх релігійних потреб та зміцнення морально-психологічного стану військовослужбовців;

- брати участь в організації благодійної допомоги військовослужбовцям та членам їх сімей ${ }^{31}$.

Військовий священик зобов'язувався: додержуватись вимог чинного законодавства та цього Положення; належно виконувати покладені на нього обов'язки, дотримуватись трудової дисципліни; узгоджувати 3 командуванням військових частин час та місце проведення богослужінь або інших релігійних заходів; забезпечувати релігійну та духовну підтримку Збройним Силам України; брати участь у проведенні з особовим складом заходів, направлених на дотримання здорового способу життя, зміцнення військової дисципліни та попередження самогубств; надавати командуванню військових частин методичну допомогу з питань релігії та іiі впливу на всі аспекти військової діяльності; організовувати задоволення релігійних потреб або забезпечувати право військовослужбовця, який сповідує іншу релігію, на його особисту зустріч із священнослужителем своєї релігійної організації; доброзичливо ставитися до всіх військовослужбовців незалежно від їхніх релігійних поглядів й уподобань i не примушувати до участі в релігійних обрядах (церемоніях); толерантно ставитися до представників інших конфесій чи релігій, утримуватися від заяв чи дій, які можуть спровокувати релігійну неприязнь, нетерпимість, ворожнечу серед військовослужбовців; співпрацювати 3 військовими священиками (капеланами) інших

${ }^{31}$ Там само. 
релігійних організацій для забезпечення релігійних потреб військовослужбовців; не допускати міжконфесійних поділів та суперечок; брати участь у роботі з утвердження пріоритетності високоморальних, гуманних норм, культури поведінки у взаєминах між військовослужбовцями; дотримуватися вимог законодавства України про державну таємницю та захист іншої інформації 3 обмеженим доступом та ін. ${ }^{32}$.

Також у 2017 р. у Верховній Раді України було зареєстровано декілька законопроектів про військове капеланство, проте, як відзначали аналітики, «державі потрібен єдиний документ, який би передбачав цілісну програму капеланського служіння ${ }^{33}$. «В парламенті вже є відповідні законопроекти, і ці документи на порядку денному. Але їх автори, народні депутати Юрій Мірошниченко та Семен Семенченко, згодні зняти свої законопроекти на користь спільного, створеного як консенсус церков і громадської спільноти. Має бути єдиний законопроект, що поєднав би позиції всіх конфесій і громадськості», - відзначав о. Любомир Яворський ${ }^{34}$. За його словами, під час розробки нового документа враховуватиметься досвід капеланського служіння тих країн світу, які мають відповідні закони. У ньому, зокрема, мають бути чітко окреслені питання статусу військового капелана, його соціального пакета ${ }^{35}$.

\section{2. Розвиток інституту військового капеланства в Україні}

Як бачимо, до певної міри поворотним у розвитку інституту капелантва в Україні став 2017 рік. Із 20 лютого 2017 р. Національна гвардія України запровадила службу військового капеланства. Священнослужителі різних конфесій отримали змогу влаштовуватися на роботу у Нацгвардію як працівники, за трудовим договором, i працювати у військових частинах тилу або у прифронтовій зоні ${ }^{36}$. Цій події передував тривалий підготовчий етап: у 2014-2016 рр. психологічною службою Нацгвардії було проведено понад 40 міжнародних навчань, семінарів, зборів щодо

32 Там само.

33 В УГКЦ сподіваються на ухвалення закону про капеланство до літа. URL : https://www.ukrinform.ua/rubric-society/2363188-v-ugkc-spodivautsa-nauhvalenna-zakonu-pro-kapelanstvo-do-lita.html.

${ }^{34}$ Там само.

35 Там само.

Нацгвардія "легалізувала" роботу капеланів в АТО. URL : https://www.ukrinform.ua/rubric-society/2194342-nacgvardia-legalizuvala-robotukapelaniv-v-ato.html. 
підвищення професійної підготовки військових психологів і капеланів (залучалися вітчизняні та зарубіжні експерти з Ізраїлю, Данії, Франції, Польщі, Литви, Латвії, Естонії, США та інших країн) ${ }^{37}$.

Таким чином, новації в законодавчій сфері дозволили капеланам різних конфесій офіційно працювати в лавах Національної гвардії України як працівникам за трудовим договором, а також військових частинах тилу або у прифронтовій зоні ${ }^{38}$. Проте суспільні дискусії щодо статусу капеланства в Україні не припинялися. «Ми маємо неоднозначну думку щодо моделі військового капеланства - чи він має бути військовослужбовцем, як того хотіли би певні конфесії, чи залишатися цивільною особою, думку про що висловили військові, які за даних умов такий формат співпраці вважають невчасним», наголошували у Раді у справах душпастирської опіки при $\mathrm{MOY}^{39}$.

Щодо конфесійного розподілу капеланів у цей період, то на офіційних посадах капеланів у силових структурах $85 \%$ - це Православна церква України, близько 18 \% - УГКЦ і 1-2\% протестантські церкви. Української православної церкви (Московського патріархату) на офіційних посадах не було ${ }^{40}$. В УГКЦ нараховувався 161 військовий капелан, а 3 початку АТО церквою було здійснено понад 600 ротацій ${ }^{41}$. Водночас у військових частинах Національної гвардії для офіційного влаштування було введено 44 посади для військових священиків (до цього часу на громадських засадах в Нацгвардії співпрацювали 67 священиків різних конфесій). «У Національній гвардії введено в дію інститут військового духовенства. Вже здійснюється підбір священнослужителів для укомплектування 44 посад капеланів у різних частинах Національної гвардії України», - відзначав з нагоди

${ }^{37}$ Нацгвардія провела понад 40 навчань для військових психологів і капеланів. URL : https://www.ukrinform.ua/rubric-society/2194396-nacgvardia-provela-ponad-40navcan-dla-vijskovih-psihologiv-i-kapelaniv.html.

38 Нацгвардія "легалізувала" роботу капеланів в ATO. URL : https://www.ukrinform.ua/rubric-society/2194342-nacgvardia-legalizuvala-robotukapelaniv-v-ato.html.

39 В УГКЦ сподіваються на ухвалення закону про капеланство до літа. URL : https://www.ukrinform.ua/rubric-society/2363188-v-ugkc-spodivautsa-nauhvalenna-zakonu-pro-kapelanstvo-do-lita.html.

40 Як капелани допомагають захисникам України на Донбасі і в Криму: інтерв'ю 3 протоієреєм Тарасом Мельником. URL : https://religionpravda.com.ua/?p=45523.

${ }_{41}$ Сто військових капеланів 3 досвідом ATO зібралися на з'їзд. URL : https://www.ukrinform.ua/rubric-society/2362444-sto-vijskovih-kapelaniv-z-dosvidomato-zibralisa-na-zizd.html. 
3-ї річниці створення Національної гвардії України глава держави ${ }^{42}$. Військові священики забезпечувалися грошима під час відрядження в АТО i співпрацювали 3 психологами, опікуючись душами військовослужбовців ${ }^{43}$. «На сьогодні священик, духівник повноцінний співробітник Національної гвардії України. Сьогодні він має право, якщо військова частина виїжджає в зону проведення АТО, то військовий священик може виїхати разом 3 ними. Для нього виписується лист відрядження, він отримує кошти за свою роботу під час відрядження i працює в колективі, разом 3 військовослужбовцями», - пояснювали у Національній гвардії України ${ }^{44}$.

Також 3-8 липня 2017 р. Національна гвардія України провела на полігоні у Львівській області навчання військових капеланів (навчальний центр у м. Золочів) ${ }^{45}$. 15 серпня того ж року у Головному управлінні Національної Гвардії України заступник командувача по роботі 3 особовим складом генерал-майор Я. Сподар вперше вручив посвідчення учасника бойових дій капелану, що займався духовною опікою військовослужбовців Навчального центру Нацгвардії. «Протоієрей Кулицький Андрій Романович з березня 2017 року офіційно є військовим священиком (капеланом) навчального центру НГУ, що на Львівщині. Ще до призначення на посаду він на волонтерських засадах працював 3 військовослужбовцями Навчального центру. 3 початком АТО неодноразово виїжджав 3 гвардійцями на схід України, де займався душпастирською опікою особового складу. Цим самим завоював довіру, великий авторитет та повагу», - йшлосяся у місцевій пресі ${ }^{46}$.

Одним із найпроблемніших питань залишалася служба духівників УПЦ (МП) у лавах Збройних Сил України, Національній Гвардії України. Власне серед православних церков, котрі діяли у діють в Україні, винятковим джерелом загрози національним

42 У Нацгвардію підбирають 44 капелани. URL : https://www.ukrinform.ua/ rubric-society/2200600-u-nacgvardiu-pidbiraut-44-kapelani.html.

43 Нацгвардія «легалізувала» роботу капеланів в АTO. URL : https://www.ukrinform.ua/rubric-society/2194342-nacgvardia-legalizuvala-robotukapelaniv-v-ato.html.

${ }_{45}^{44}$ Там само.

СRL Сьогодні розпочинаються навчання військових капеланів. navcanna-vijskovih-kapelaniv.html.

46 Перший капелан Нацгвардії отримав посвідчення учасника бойових дій. URL : https://www.ukrinform.ua/rubric-society/2286782-persij-kapelan-nacgvardiiotrimav-posvidcenna-ucasnika-bojovih-dij.html. 
інтересам та національній безпеці держави виступає УПЦ (МП) духівництво цієї Церкви вирізняється здатністю культивувати сепаратистські настрої та продукувати конфліктогенну атмосферу в українському суспільстві, виступає потужним інструментом для забезпечення реалізації політики й ідеології «руского міра» ${ }^{47}$.

Представники Нацгвардії заявляли, що діяльність священиків УПЦ Московського патріархату на капеланській службі не заборонена. Проте на територію військових частин не могли бути недопущені священики релігійних організацій, центри яких знаходяться на території країни-агресора. «Наказом МВС затверджено Положення про службу військового духовенства (капеланську службу) у Національній гвардії України, проте не заборонено, як подають у деяких ЗМІ, діяльність священиків УПЦ Московського патріархату», - сказано в офіційному повідомленні ${ }^{48}$. Відповідно до ст. 35 Конституції України («Кожен має право на свободу слова і віросповідання») жоден нормативного-правовий акт не забороняв і не обмежував військовослужбовців Нацгвардії у свободі світогляду та віросповідання, свободі сповідувати будь-яку релігію або не сповідувати жодної, безперешкодно відправляти одноосібно чи колективно релігійні культи та ритуальні обряди, вести релігійну діяльність 49 .

Загалом у 2014-2018 pр. у Збройних силах України відбулось майже п'ять тисяч ротацій священнослужителів, які здійснюють душпастирську опіку над захисниками України ${ }^{50}$. Додамо, що базовим нормативним документом, який регламентував діяльність священнослужителів у ЗСУ, став наказ Генштабу № 417 від 20 листопада 2018 року, яким встановлювався порядок організації та використання духовних центрів ЗСУ. Відповідно до нього заборонялося допускати до духовних центрів на території військових частин представників релігійних організацій, центри яких знаходяться на території країн-агресорів, діяльність яких може спричинити міжконфесійні конфлікти у військовому середовищі та

${ }^{47}$ Проблеми служби військових капеланів України в умовах агресії Російської Федерації: аналітична доповідна. URL : https://niss.gov.ua/sites/default/files/ 2016-08/kapelanu-d05c2.pdf.

${ }_{48}$ Священикам УПЦ МП не забороняли служити капеланами - Нацгвардія. URL : https://www.ukrinform.ua/rubric-society/2288078-svasenikam-upc-mp-nezaboronali-sluziti-kapelanami-nacgvardia.html.

${ }^{49}$ Там само.

50 В армії пройшли ротацію майже п'ять тисяч капеланів - Генштаб. URL : https://www.ukrinform.ua/rubric-ato/2609554-v-armii-projsli-rotaciu-majze-pat-tisackapelaniv-genstab.html. 
негативно вплинути на морально-психологічний стан особового складу $3 \mathrm{Cy}^{51}$. У цей же період у ЗСУ було введено 105 посад військових капеланів, з яких укомплектовано $68^{52}$.

Потреба ЗСУ у військових священнослужителях значно перевищувала кількість капеланів. «У бойовій бригаді може бути два капелани, цього недостатньо. Навіть якщо лише частина бригади знаходиться в зоні бойових дій, той обсяг роботи, який лягає на плечі капелана, надзвичайно великий. I ми будемо намагатися у 2019 році ввести посади не в окремих частинах, окремих батальйонах, а в лінійних батальйонах», - наголошували у Генштабі $3 \mathrm{Cy}^{53}$.

Отже, якщо бригада налічуватиме п'ять батальйонів, намагатимуться вводити п'ять посад військових капеланів, для того щоб у кожного підрозділу був свій духовний наставник. Один капелан повинен був би надавати душпастирську допомогу 400-500 військовим. Таким чином, серед основоположних завдань на 2019 рік щодо подальшого розвитку служби військового духовенства - створення та розвиток духовних центрів на території військових частин, відбір та призначення священнослужителів на вакантні посади капеланів, робота над законом України «Про капеланську службу» та ін. ${ }^{54}$

«Ми є свідками того, як інститут капеланства за останні кілька років помітно розвинувся та утвердився. На жаль, досі питання військового капеланства не унормоване 3 боку держави, яка повинна чітко означити роль капелана в українській армії. Також $\epsilon$ вкрай необхідним, щоби кожен капелан був соціально захищеним. В законі має відображатися те, що підтверджене самим життям: українська армія потребує капеланів, бо їхнє духовне служіння життєво необхідне воїнам», - констатував митрополит Епіфаній ${ }^{55}$.

Митрополит також зауважив, що капелани відіграють важливу роль i поза фронтом, зокрема, підтримуючи родини військовослужбовців, а також працюючи у реабілітаційних центрах,

51 Там само.

52 Там само.

53 Там само.

${ }_{55}^{54}$ Там само.

55 Держава має чітко визначити роль капеланства в українській армії - Епіфаній. URL : https://www.ukrinform.ua/rubric-society/2833028-derzava-mae-citko-viznaciti-rolkapelanstva-v-ukrainskij-armii-epifanij.html. 
де уражені війною не тільки фізично, а й морально, українські військові прагнуть повернутись до звичайного мирного життя» ${ }^{56}$.

6 червня 2019 р. Верховна Рада України ухвалила у першому читанні законопроєкт про військове капеланство. «Метою розробки проекту закону $\epsilon$ необхідність закріплення правових засад iз забезпечення реалізації конституційного права особового складу Збройних Сил, інших військових формувань та правоохоронних органів спеціального призначення на свободу світогляду i віросповідання шляхом впровадження інституту військового капеланства», - йдеться в Пояснювальній записці до законопроекту. Законопроектом, зокрема, передбачається врегулювати на законодавчому рівні організаційно-правові засади взаємодії релігійних організацій 3 Міністерством оборони, органами управління Збройних Сил України, Державної спеціальної служби транспорту Національної гвардії, Державної прикордонної служби, Держслужби спеціального зв'язку та захисту інформації України щодо забезпечення реалізації права на свободу віросповідання, душпастирської опіки особового складу Збройних Сил, інших військових формувань, правоохоронних органів спеціального призначення ${ }^{5}$.

Проект закону визначає, що військове капеланство - діяльність капеланських об'єднань, військових капеланів та військових капеланів-волонтерів із забезпечення реалізації права на свободу віросповідання, душпастирської опіки особового складу Збройних Сил, інших військових формувань та правоохоронних органів спеціального призначення. У пояснювальній записці зазначалося, що до організації та забезпечення виконання завдань військового капеланства залучатимуться всеукраїнський міжконфесійний дорадчий орган 3 питань військового капеланства, підрозділи (посадові особи) з питань військового духовенства (капеланської служби) і командування військових частин (органів, підрозділів) Збройних Сил, інших військових формувань та правоохоронних органів спеціального призначення, капеланські об'єднання, військові капелани і військові капелани-волонтери.

Паралельно із законодавчим процесом тривав процес визнання капеланів добровольцями АТО / ОСС. Зокрема, у 2019 р. Луцьку

${ }^{56}$ Там само.

57 Рада ухвалила у першому читанні законопроект про військове капеланство. URL : https://www.ukrinform.ua/rubric-society/2716391-rada-uhvalila-u-persomucitanni-zakonoproekt-pro-vijskove-kapelanstvo.html. 
перші десять капеланів, які надавали духовну підтримку бійцям АТО/ООС, отримали посвідчення добровольців і подяки від Волинської обласної ради. Як нагадали в облраді, на одній із сесій депутатами було прийнято рішення «Про визнання статусу бійцівдобровольців, які брали участь у захисті територіальної цілісності та державного суверенітету в російсько-українській війні» 58 . Пізніше в цей документ внесли зміни, якими передбачено визнання статусу капеланів-добровольців.

«Переконаний, що й надалі ми всі, представницька та виконавча гілки влади, а також громадські організації, будемо тісно працювати в плані визнання воїнів-добровольців, які віддавали своє життя i здоров'я заради Незалежності України. Дякую за вашу місію i жертовність», - зазначав перший заступник голови обласної ради Юрій Поліщук. Директор департаменту соцзахисту ОДА О. Гобод повідомила, що капелани-добровольці отримуватимуть щорічну виплату в розмірі 10 тис. грн ${ }^{59}$.

Водночас в Івано-Франківській області у 2020 році військові капелани, які захищали суверенітет України на сході держави, також отримали статус добровольців АТО-ООС. Відповідні зміни до рішення «Про визнання бійців-добровольців, які брали участь у захисті територіальної цілісності та державного суверенітету на сході України» депутати ухвалили на сесії облради. «Визнати осіб, з числа жителів Івано-Франківської області, які перебували чи перебувають у складі добровольчих формувань, що були утворені або самоорганізувались для захисту незалежності, суверенітету, територіальної цілісності держави, але в подальшому не увійшли до складу Збройних сил України, Міністерства внутрішніх справ України, Національної гвардії України та інших утворених відповідно до законів України військових формувань та правоохоронних органів, бійцями-добровольцями, які брали участь у захисті територіальної цілісності та державного суверенітету на сході України, а також осіб, які виконували або виконують функції військових священників (капеланів) як добровольці, - капеланамидобровольцями АТО-ООС», - йшлося у рішення облради ${ }^{60}$.

58 На Волині перші десять капеланів отримали посвідчення добровольців ATO/OOC. URL : https://www.ukrinform.ua/rubric-regions/2761785-na-volini-persidesat-kapelaniv-otrimali-posvidcenna-dobrovolciv-atooos.html.

${ }_{60}^{59}$ Там само.

${ }^{60}$ На Прикарпатті капелани отримали статус добровольців ATO-OOC. URL : https://www.ukrinform.ua/rubric-regions/3035561-na-prikarpatti-kapelani-otrimali-statusdobrovolciv-atooos.html. 


\section{ВИСНОВКИ}

На думку сучасних аналітиків, аналіз взаємовідносин держави i військових формувань 3 релігійними організаціями показує, що процес задоволення релігійних потреб віруючих військовослужбовців шляхом запровадження служби військових капеланів є складним і суперечливим ${ }^{61}$. Тільки у середині 1990-х рр. у різних конфесіях починають формуватися напрями діяльності щодо задоволення духовних потреб військовослужбовців, призначаються відповідальні за дані напрями, створюються відповідні структури. Після Помаранчевої революції (2004 р.) почалась активізація військово-церковного співробітництва, підготовлено директиву Міністра оборони України «Про впорядкування питань задоволення релігійних потреб військовослужбовців Збройних Сил України» від 21 квітня 2006 року, у структурі Департаменту гуманітарної політики Міністерства оборони України створено сектор роботи 3 релігійними організаціями (2008 р.), а згодом Раду у справах душпастирської опіки при Міністерстві оборони України. Значний кроком у становленні інституту капеланства в Україні стала підготовка Концепції душпастирської опіки у Збройних Силах України (2011р.), Положення про службу військового духовенства (капеланську службу) у Збройних Силах України» (2015р.). На жаль, сьогодні Верховна Рада України не ухвалила закон, який би на законодавчому рівні регламентував інститут військового капеланства в Україні.

\section{АНОТАЦІЯ}

Розглянуто процес становлення та розвитку інституту капеланства в незалежній Україні. Відзначено, що в період президенства Л. Кучми у конфесіях нашої держави створено перші інституції, основне завдання яких полягало в задоволенні духовних потреб військовослужбовців. Зазначено, що директиви Міністра оборони України «Про впорядкування питань задоволення релігійних потреб військовослужбовців Збройних Сил України»

${ }^{61}$ Проблеми служби військових капеланів України в умовах агресії Російської Федерації: аналітична доповідна. URL : https://niss.gov.ua/sites/default/files/ 2016-08/kapelanu-d05c2.pdf. 
(2006 р.), Концепції душпастирської опіки у Збройних Силах України (2011р.), Положення про службу військового духовенства (капеланську службу) у Збройних Силах України» (2015р.) піднесли на якісно вищий рівень вищезазначені проблеми та створили підгрунтя для розвитку інституту військового капеланства. Констатовано, що значні повноваження надано Раді у справах душпастирської опіки при Міністерстві оборони України. Доведено необхідність законодавчого врегулювання проблеми функціонування інституту військового капеланства в умовах сучасної гібридної війни Російської Федерації проти України.

\section{ЛІТЕРАТУРА}

1. Бути поруч - завдання капелана. URL : http://olivebranch.org.ua/.

2. Проблеми служби військових капеланів України в умовах агресії Російської Федерації: аналітична доповідна. URL : https://niss.gov.ua/sites/default/files/2016-08/kapelanu-d05c2.pdf.

3. Капелани. На службі Богу і Україні/ Уклад. : Тетяна Ковтунович, Тетяна Привалко ; Укр. ін-т нац. пам'яті. Київ : ФОП Гончарук А.Б., 2019. 620 с.

4. «Капелани. На службі Богу і Україні». Інститут презентує спогади військових священиків. URL : https://uinp.gov.ua/prescentr/novyny/3104.

5. Ярмусь С. Збройні Сили і феномен військового капеланства. Армія і духовність: свобода совісті та віровизнання. Матеріали міжнародної науково-практичної конференції. Київ, 1995. C. 111-112.

6. Уткін О. Конфлікти на національно-конфесійному грунті у Збройних Силах України та заходи 3 їх запобігання. Українське релігієзнавство. Київ, 1997. № 5. С. 52-55.

7. Танчер В. Свобода совісті - важлива умова культурного розвитку особи військовослужбовця. Украӥнське релігієзнавство. Бюлетень. Київ, 1998. № 7. С. 31-33.

8. Рабінович П.М., Коваленко С.О. Свобода віросповідання i загальний військовий обов'язок. Драгоманівський збірник «Вільна спілка» та сучасний український конституціоналізм. Львів, 1996. С. 221-226. 
9. Журавський В. Церква і армія: співпраця у формуванні воїнагромадянина. Вечірній Київ. 1996. 30 жовтня С. 6.

10.Дробко Е. Державне регулювання у сфері забезпечення душпастирської опіки військовослужбовців Збройних Сил України та створення інституту військового капеланства. URL : http://lvivacademy.com/vidavnitstvo_1/visnyk14/fail/drobko.pdf.

11.Чорна I. Церква і армія: зарубіжний досвід та українські реалії. URL : https://www.ngu.gov.ua/en/node/4748.

12.3діорук C. Служба військових капеланів: досвід функціонування в іноземних збройних силах. Стратегічні пріоритети. 2009. № 1(10) . С. 236-245.

13. Концепція душпастирської опіки у Збройних Силах України. URL : https://www.mil.gov.ua/diyalnist/zvyazki-z-gromadskistyu/rada-uspravah-dushpastirskoi-opiki-pri-ministerstvi-oboroni-ukraini/normativnidokumenti-ta-metodichni-rekomendaczii/2014/07/08/konczepcziyadushpastirskoi-opiki-u-zbrojnih-silah-ukraini/.

14.Найближчим часом в українському війську буде запроваджено інститут військового духовенства. URL : https://www.mil.gov.ua/special/news.html?article=23111.

15.Проблеми служби військових капеланів України в умовах агресії Російської Федерації: аналітична доповідна. URL : https://niss.gov.ua/sites/default/files/2016-08/kapelanu-d05c2.pdf.

16.Про службу військового духовенства (капеланську службу) у Збройних Силах, Національній гвардії, Державній спеціальній службі транспорту та Державній прикордонній службі: Розпорядження Кабінету Міністрів України. URL : https://zakon.rada.gov.ua/laws/show/677-2014-\%D1\%80\#Text.

17.Про затвердження Положення про службу військового духовенства (капеланську службу) у Збройних Силах України : Наказ Міністерства оборони України. URL : https://zakon.rada.gov.ua/laws/show/z0010-17\#Text.

18.В УГКЦ сподіваються на ухвалення закону про капеланство до літа. URL : https://www.ukrinform.ua/rubric-society/2363188-vugkc-spodivautsa-na-uhvalenna-zakonu-pro-kapelanstvo-do-lita.html.

19.Нацгвардія «легалізувала» роботу капеланів в АТО. URL : https://www.ukrinform.ua/rubric-society/2194342-nacgvardialegalizuvala-robotu-kapelaniv-v-ato.html. 
20.Нацгвардія провела понад 40 навчань для військових психологів і капеланів. URL : https://www.ukrinform.ua/rubricsociety/2194396-nacgvardia-provela-ponad-40-navcan-dla-vijskovihpsihologiv-i-kapelaniv.html.

21.В УГКЦ сподіваються на ухвалення закону про капеланство до літа. URL : https://www.ukrinform.ua/rubric-society/2363188-vugkc-spodivautsa-na-uhvalenna-zakonu-pro-kapelanstvo-do-lita.html.

22. Як капелани допомагають захисникам України на Донбасі і в Криму: інтерв'ю 3 протоієреєм Тарасом Мельником. URL : https://religionpravda.com.ua/?p=45523.

23. Сто військових капеланів з досвідом АТО зібралися на з'їзд. URL : https://www.ukrinform.ua/rubric-society/2362444-sto-vijskovihkapelaniv-z-dosvidom-ato-zibralisa-na-zizd.html.

24.У Нацгвардію підбирають 44 капелани. URL : https://www.ukrinform.ua/rubric-society/2200600-u-nacgvardiupidbiraut-44-kapelani.html.

25. Сьогодні розпочинаються навчання військових капеланів. URL : https://www.ukrinform.ua/rubric-society/2258027-sogodnirozpocinautsa-navcanna-vijskovih-kapelaniv.html.

26. Перший капелан Нацгвардії отримав посвідчення учасника бойових дій. URL : https://www.ukrinform.ua/rubric-society/2286782persij-kapelan-nacgvardii-otrimav-posvidcenna-ucasnika-bojovihdij.html.

27. Священикам УПЦ МП не забороняли служити капеланами Нацгвардія. URL : https://www.ukrinform.ua/rubric-society/2288078svasenikam-upc-mp-ne-zaboronali-sluziti-kapelanami-nacgvardia.html.

28.В армії пройшли ротацію майже п'ять тисяч капеланів Генштаб. URL : https://www.ukrinform.ua/rubric-ato/2609554-v-armiiprojsli-rotaciu-majze-pat-tisac-kapelaniv-genstab.html.

29. Держава має чітко визначити роль капеланства в українській армії - Епіфаній. URL : https://www.ukrinform.ua/rubricsociety/2833028-derzava-mae-citko-viznaciti-rol-kapelanstva-vukrainskij-armii-epifanij.html.

30. Рада ухвалила у першому читанні законопроект про військове капеланство. URL : https://www.ukrinform.ua/rubric-society/2716391rada-uhvalila-u-persomu-citanni-zakonoproekt-pro-vijskovekapelanstvo.html. 
31.На Волині перші десять капеланів отримали посвідчення добровольців ATO/OOC. URL : https://www.ukrinform.ua/rubricregions/2761785-na-volini-persi-desat-kapelaniv-otrimali-posvidcennadobrovolciv-atooos.html.

32.На Прикарпатті капелани отримали статус добровольців ATO-OOC. URL : https://www.ukrinform.ua/rubric-regions/3035561na-prikarpatti-kapelani-otrimali-status-dobrovolciv-atooos.html.

Information about the author: Tkachuk Pavlo Oleksandrovuch, Adjunct

Hetman Petro Sahaidachnyi National Army Academy 32, Heroiv Maidanu str., Lviv, 79026, Ukraine 